\title{
Synthesis and Biological Activity of Three New $5 \alpha$-Hydroxy Spirostanic Brassinosteroid Analogues
}

\author{
Caridad R. Rodríguez ${ }^{*, a}$, Yohan I. Villalobos ${ }^{a}$, Esther A. Becerra ${ }^{a}$, Francisco C. Manchado $^{a}$, \\ Deysma C. Herrera ${ }^{a}$ and Marco A. T. Zullo ${ }^{b}$ \\ ${ }^{a}$ Natural Products Laboratory, Faculty of Chemistry, University of Havana, Calzada de Zapata y Calle G, Vedado, \\ Habana 10400, Cuba \\ ${ }^{b}$ Laboratório de Fitoquímica, Instituto Agronômico, CP 28, 13001-970 Campinas - SP, Brazil
}

\begin{abstract}
Três novos análogos espirostânicos de brassinosteróides foram sintetizados pela primeira vez a partir de diosgenina: (25R)-2 $\alpha, 3 \alpha$-epoxi-5 $\alpha$-hidroxiespirostan-6-ona (3), (25R)-2 $\beta, 3 \alpha, 5 \alpha$-triidroxiespirostan-6-ona (5) e (25R)-2 $\beta$-metoxi-3 $\alpha, 5 \alpha$-diidroxiespirostan-6-ona (6). A substância 3 mostrou acentuada atividade promotora de crescimento vegetal no bioensaio de elongação do hipocótilo e expansão do cotilédone de rabanete, enquanto a substância 6 mostrou-se fitotóxica.
\end{abstract}

Three new spirostanic brassinosteroid analogues have been synthesized for the first time from diosgenin: (25R)-2 $\alpha, 3 \alpha$-epoxy-5 $\alpha$-hydroxyspirostan-6-one (3), (25R)-2 $\beta, 3 \alpha, 5 \alpha$-trihydroxyspirostan6-one (5) and (25R)-2 $\beta$-methoxy-3 $\alpha, 5 \alpha$-dihydroxyspirostan-6-one (6). In the radish hypocotyl elongation and cotyledon expansion bioassay compound $\mathbf{3}$ showed plant growth promoting activity whereas $\mathbf{6}$ was shown to be phytotoxic.

Keywords: steroids, brassinosteroid analogues, diosgenin

\section{Introduction}

Brassinosteroids (BS) are steroidal phytohormones with high plant growth-promoting and anti-stress effects. ${ }^{1}$ The effects of BS on crop yield and stress tolerance in agronomical important plants had been evaluated in several greenhouse and field trials. ${ }^{2}$

However, the low abundance of BS in natural sources and the difficulty of their synthesis have stimulated several workers to employ more readily available analogues in field trials. Previous reports indicate that spirostans can serve as raw materials for the synthesis of a variety of compounds with plant growth-promoting activity. ${ }^{3}$

Taking into account the different effects showed for some analogues of BS containing additional $5 \alpha$-hydroxy group in addition to the 6-keto function ${ }^{4,5}$ and in order to enlarge studies of the effects on bioactivity elicited by introducing a hydroxyl group at C-5 with $\alpha$-configuration in the molecule, in this paper we report the synthesis and bioactivity of three new $5 \alpha$-hydroxy spirostanic BS analogues from diosgenin.

\footnotetext{
* e-mail: caridad@fq.uh.cu
}

\section{Results and Discussion}

\section{Synthesis and structural elucidation}

The synthesis of the new compounds $(\mathbf{3}, \mathbf{5}$ and $\mathbf{6})$ is summarized in Scheme 1. Key compound $\mathbf{2}$ was obtained in six steps from diosgenin ${ }^{6}$ by a similar procedure developed for the synthesis of 5-hydroxy-5 $\alpha$-stigmasta2,22-dien-6-one from stigmasterol. ${ }^{5}$

Treatment of olefin 2 with 3-chloroperoxybenzoic acid (MCPBA) in methylene chloride at room temperature for $1 \mathrm{~h}$ in the dark afforded the $\alpha$-epoxide 3 as the major product $(68 \%)$. Its structure was established as a result of analysis of ${ }^{1} \mathrm{H}-{ }^{-1} \mathrm{H}-\mathrm{COSY}$ spectrum, in which the signals for the protons at $\mathrm{C}-2$ and $\mathrm{C}-3$ appear at the characteristic positions for $\alpha$-epoxy derivatives at $\delta 3.27 \mathrm{ppm}$ and 3.56 ppm, respectively. ${ }^{13} \mathrm{C}$ NMR analysis of compound 3 was also consistent with the assigned stereochemistry (see table 1 in experimental section).

Target compounds 5 and $\mathbf{6}$ were obtained through a bifurcation of this synthetic route. Acid hydrolysis of epoxide 3 with perchloric acid/acetone afforded, besides $7 \%$ of cis-diol $\mathbf{4}$, the expected trans-diol $\mathbf{5}$ as the major compound in $85 \%$ yield. Formation of $2 \beta, 3 \beta, 5 \alpha$ - 


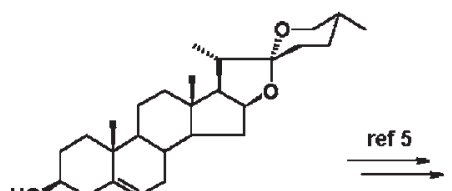

1

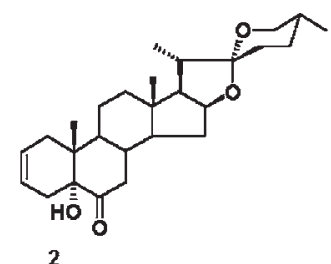

2

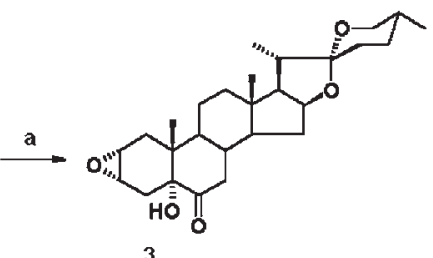

3

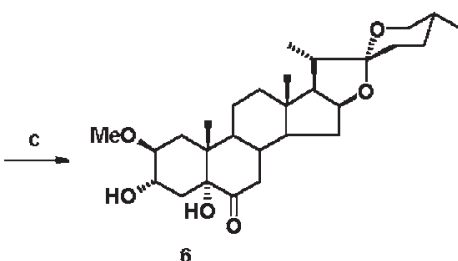

6

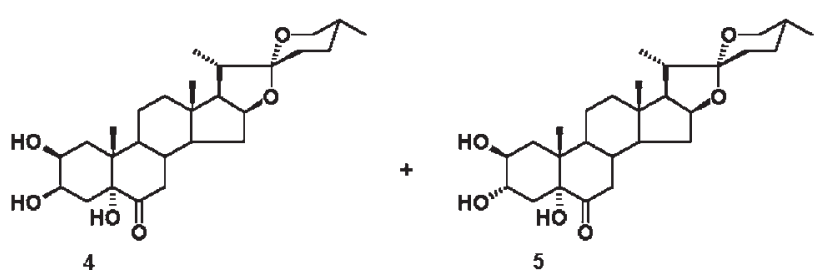

Scheme 1. Preparation of $5 \alpha$-hydroxyspirostane BS analogues. Reagents and conditions: a) $\mathrm{MCPBA} \mathrm{CH}_{2} \mathrm{Cl}_{2 ;}$ b) $\mathrm{HClO}_{4} / \mathrm{H}_{2} \mathrm{O} / \mathrm{Me}_{2} \mathrm{CO}$; c) $\mathrm{HClO} /$ $\mathrm{H}_{2} \mathrm{O} / \mathrm{MeOH}$.

trihydroxy compound 4 can be explained either by a $S_{N} 2$ (Scheme 2) or a $S_{N} 1$ (Scheme 3) mechanism, or both simultaneously. Similarly, methanolysis of the epoxide $\mathbf{3}$ in acid medium produced (25R)- $2 \beta$-methoxy- $3 \alpha, 5 \alpha$ dihydroxyspirostan-6-one (6) in $46 \%$ yield.

Configurations at C-2 and C-3 in $\beta$-cis-diol 4 were established by comparison with chemical shifts and coupling constants reported for this compound. ${ }^{6}$ The transdiol structure for compound $\mathbf{5}$ was assigned on the basis of the downfield shift of the signals for the protons 2 and 3 at $\delta 3.89 \mathrm{ppm}$, whereas the position of the protons $7 \mathrm{did}$ not change significantly. ${ }^{13} \mathrm{C}$ NMR analysis of this compound was also consistent with the assigned structure (see Table 1). The configuration and position of the methoxy group in the compound 6 was established on the basis of a NOEdifference experiment. NMR analysis of the steroid $\mathbf{6}$
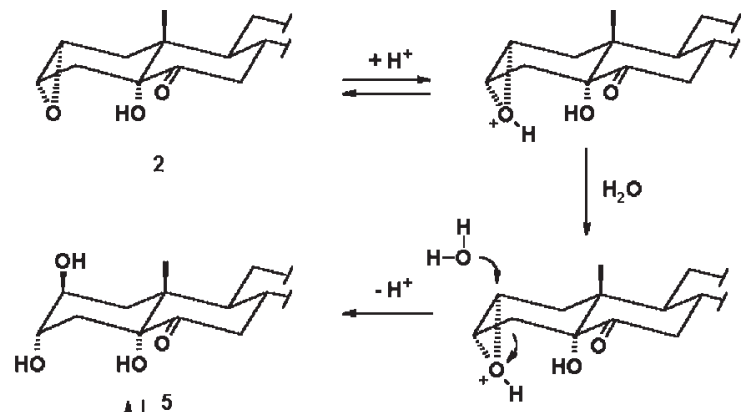

$\uparrow^{5}+\mathrm{H}_{2} \mathrm{O}+\mathrm{H}^{+}$

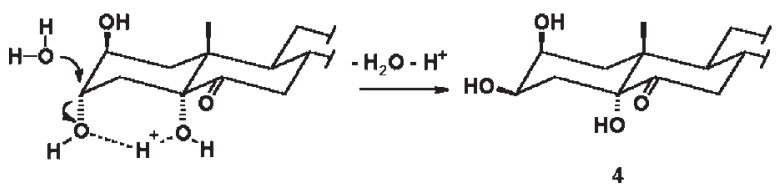

Scheme 2. Postulated $S_{N} 2$ mechanism for the formation of $\beta$-cis diol 4.

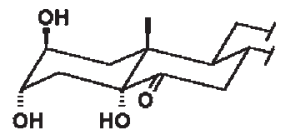

$\|^{5}-\mathrm{H}^{+}$
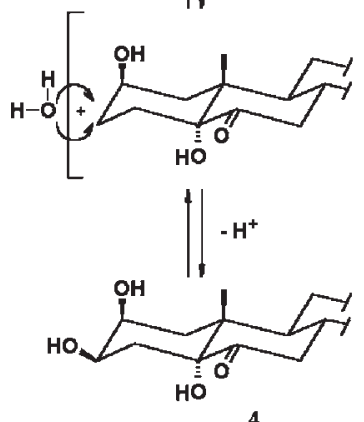

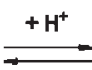

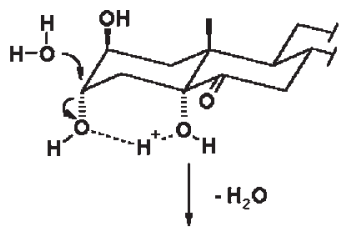
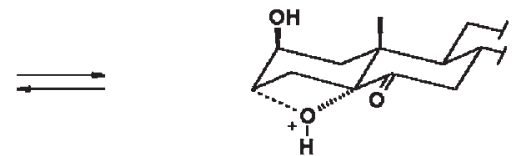

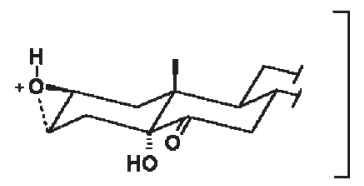

Scheme 3. Postulated $S_{N} 1$ mechanism for the formation of $\beta$-cis diol 4. 
showed that its structure is as depicted in the formula (see Experimental section).

\section{Biological activity}

The biological activity of the compounds $\mathbf{3 , 5}$ and $\mathbf{6}$ was evaluated by the radish (Raphanus sativus L.) hypocotyl elongation and cotyledon expansion bioassay. The highest growth-promoting activity was observed at $10^{-5} \mathrm{mg} \mathrm{mL}^{-1}$, at which the radish hypocotyls treated with epoxide 3 significantly increased their length by $20.7 \%$ over untreated control. No growth-promoting activity was observed for methoxy derivate $\mathbf{6}$, but a significant phytotoxicity was evident at $10^{-4} \mathrm{mg} \mathrm{mL}^{-1}$. The bioactivity of compound $\mathbf{5}$ was also examined, but no activity was observed at the tested concentrations.

\section{Experimental}

\section{General}

Melting points (mp) were measured on a Electrothermal 9100 apparatus and are uncorrected. IR spectra were recorded in the region of $700-4000 \mathrm{~cm}^{-1}$ in $\mathrm{KBr}$ disks on a Phillips Analytical PU 9600 FTIR or on a Shimadzu-FTIR 8300 instrument. ${ }^{1} \mathrm{H}$ and ${ }^{13} \mathrm{C}$ NMR spectra were taken in $\mathrm{CDCl}_{3}$ or DMSO- $d_{6}$ as solvent on a Bruker ACF-250 spectrometer at 250.13 and $62.9 \mathrm{MHz}$, respectively. Chemical shifts $(\delta)$ are given in ppm downfield from tetramethylsilane as the internal standard, and coupling constants $(J)$ values are in Hertz $(\mathrm{Hz})$. Number of directly attached protons for each carbon was established by DEPT pulse sequence. Elemental analyses were obtained on a Carlo-Erba EA-1108 Automost microanalyzer. Unless otherwise indicated, all solvents and reagents used were of commercial grade. Reactions were monitored by TLC on precoated plates with silica gel $60 \mathrm{G}$ (Merck, 105554). Column chromatography was carried out on silica gel 60 (0.04-0.063 mm, Merck).

\section{Synthesis of compounds}

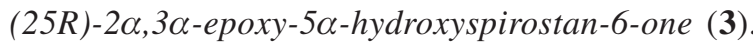
Compound $2^{6}(500 \mathrm{mg}, 0.58 \mathrm{mmol})$ in chloroform $(5 \mathrm{~mL})$ was treated with 3-chloroperoxybenzoic acid (200 mg, $1.16 \mathrm{mmol}$ ) at room temperature in darkness for $1 \mathrm{~h}$. The reaction mixture was diluted with $5 \mathrm{~mL}$ of chloroform, washed with saturated solution of sodium bicarbonate $(2$ x $3 \mathrm{~mL}$ ) and brine ( 2 x $5 \mathrm{~mL})$. The organic phase was dried with anhydrous sodium sulfate, concentrated in vacuo and the crude product was chromatographed on silica gel with n-hexane/ethyl acetate (90:10) as eluant, affording compound 3 as a white solid in $68 \%$ yield. mp 211.2 $211.7^{\circ} \mathrm{C}$ (from n-hexane/ethyl acetate). IR (KBr) $v_{\max } / \mathrm{cm}^{-1}$ : $3408\left(v_{\mathrm{OH}}\right) ; 1713\left(v_{\mathrm{C}=\mathrm{O}}\right) ; 1059$ and $1245\left(v_{\mathrm{C}-\mathrm{O}}\right) ; 983,920$, 902 and 868 (spiroketal system). ${ }^{1} \mathrm{H}$ NMR $\left(\mathrm{CDCl}_{3}\right): 0.72$ $\left(6 \mathrm{H}, \mathrm{s}, \mathrm{CH}_{3}-18\right.$ and 19); $0.76\left(3 \mathrm{H}, \mathrm{d}, J 6.6 \mathrm{~Hz}, \mathrm{CH}_{3}-27\right)$; $0.94\left(3 \mathrm{H}, \mathrm{d}, J 6.7 \mathrm{~Hz}, \mathrm{CH}_{3}-21\right) ; 2.0(1 \mathrm{H}, \mathrm{m}, \mathrm{H}-4 \beta) ; 2.38(1 \mathrm{H}$, dd, $J 1.9$ and $16.6 \mathrm{~Hz}, \mathrm{H}-4 \alpha) ; 2.61$ (1H, t, $J 12.1 \mathrm{~Hz}, \mathrm{H}-7 \alpha)$;

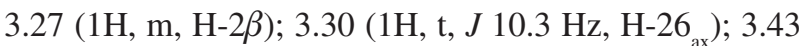
$\left(1 \mathrm{H}, \mathrm{m}, \mathrm{H}-26_{\mathrm{eq}}\right) ; 3.56$ (1H, m, H-3 $\left.\beta\right)$; 4.36 (1H, m, H-16 $\alpha$ ). ${ }^{13} \mathrm{C} \mathrm{NMR}\left(\mathrm{CDCl}_{3}\right)$ : see Table 1. Anal. Calcd. for $\mathrm{C}_{27} \mathrm{H}_{40} \mathrm{O}_{5} \mathrm{C}$ $72.94 \%, \mathrm{H} 9.02 \%$. Found C 72.89\%, H $9.06 \%$.

(25R)-2 $\beta, 3 \beta, 5 \alpha$-trihydroxy-spirostan-6-one (4) and (25R)-2 $\beta, 3 \alpha, 5 \alpha$-trihydroxyspirostan-6-one (5). A mixture of $3(220 \mathrm{mg}, 0.49 \mathrm{mmol})$, acetone $(11 \mathrm{~mL})$, water $(1.4 \mathrm{~mL})$ and $70 \%$ perchloric acid $(0.2 \mathrm{~mL})$ was stirred for $4 \mathrm{~h}$ at room temperature. Ethyl acetate $(30 \mathrm{~mL})$ was added and the organic layer was washed with brine $(3 \times 5 \mathrm{~mL})$ and sodium bicarbonate $(3 \times 5 \mathrm{~mL})$. The solvent was dried with anhydrous sodium sulfate, concentrated in vacuo and the crude product was chromatographed on silica gel with n-hexane/ethyl acetate (80:20) as eluant, first affording compound $\mathbf{4}$ in $7 \%$ yield and later compound $\mathbf{5}$ in $84 \%$ yield.

Compound 4 ((25R)-2 $\beta, 3 \beta, 5 \alpha$-trihydroxyspirostan-6one). mp 199.2-199.5 ${ }^{\circ} \mathrm{C}$ (from methanol). IR (KBr) $v_{\max } /$ $\mathrm{cm}^{-1}: 3425\left(v_{\mathrm{OH}}\right) ; 1723\left(v_{\mathrm{C}=\mathrm{O}}\right) ; 1060\left(v_{\mathrm{C}-\mathrm{O}}\right) ; 980,920,902$ and 865 (spiroketal system). ${ }^{1} \mathrm{H}$ NMR (DMSO- $\left.d_{6}\right): 0.77$ (3H, s, $\left.\mathrm{CH}_{3}-18\right) ; 0.79$ (3H, d, J 6.6 Hz, $\left.\mathrm{CH}_{3}-27\right) ; 0.91$ (3H, s, $\left.\mathrm{CH}_{3}-19\right)$; 0.97 (3H, d, J 6.7 Hz, $\left.\mathrm{CH}_{3}-21\right) ; 3.34$ (1H, t, J 10.2 $\left.\mathrm{Hz}, \mathrm{H}-26_{\mathrm{ax}}\right) ; 3.47$ (1H, m, H-26 ${ }_{\mathrm{eq}}$ ); 3.84 (1H, m, H-2 $\left.\alpha\right)$; 4.41 (1H, m, H-16); 4.45 (1H, m, H-3 $\alpha) .{ }^{13} \mathrm{C} \mathrm{NMR}\left(\mathrm{CDCl}_{3}\right)$ : see Table 1.

Compound 5 ((25R)-2 $\beta, 3 \alpha, 5 \alpha$-trihydroxyspirostan- 6 one). mp 261.4-262.3 ${ }^{\circ} \mathrm{C}$ (from methanol). IR (KBr) $v_{\max } /$ $\mathrm{cm}^{-1}: 3425\left(v_{\mathrm{OH}}\right) ; 1725\left(v_{\mathrm{C}=\mathrm{O}}\right) ; 1061$ and $1143\left(v_{\mathrm{C}-\mathrm{O}}\right) ; 920$, 902 and 865 (spiroketal system). ${ }^{1} \mathrm{H}$ NMR (DMSO- $d_{6}$ ): 0.71 (3H, s, $\left.\mathrm{CH}_{3}-18\right) ; 0.74\left(3 \mathrm{H}, \mathrm{d}, J 6.6 \mathrm{~Hz}, \mathrm{CH}_{3}-27\right) ; 0.91(3 \mathrm{H}, \mathrm{d}$, $\left.J 6.7 \mathrm{~Hz}, \mathrm{CH}_{3}-21\right)$; $0.93\left(3 \mathrm{H}, \mathrm{s}, \mathrm{CH}_{3}-19\right) ; 2.62(1 \mathrm{H}, \mathrm{t}, J 12.2$ $\mathrm{Hz}, \mathrm{H}-7 \mathrm{a}) ; 3.34$ (1H, t, J 10.2 Hz, H-26 ${ }_{\mathrm{ax}}$ ); 3.47 (1H, m, H$26_{\mathrm{eq}}$ ); 3.89 (2H, m, H-2 $\alpha$ and $\left.\mathrm{H}-3 \beta\right)$; 4.33 (1H, m, H-16). ${ }^{13} \mathrm{C} \mathrm{NMR}\left(\mathrm{CDCl}_{3}\right)$ : see Table 1. Anal. Calcd. for $\mathrm{C}_{28} \mathrm{H}_{44} \mathrm{O}_{6} \mathrm{C}$ $70.09 \%, \mathrm{H} 9.15 \%$. Found C 70.04\%, H $9.18 \%$.

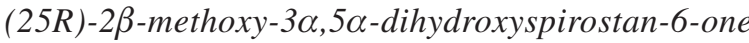
(6). A magnetically stirred mixture of $\mathbf{3}(370 \mathrm{mg}, 0.83 \mathrm{mmol})$ in methanol $(30 \mathrm{~mL})$ and $70 \%$ perchloric acid $(0.7 \mathrm{~mL})$ was refluxed for $1 \mathrm{~h}$. The reaction mixture was cooled and then sodium bicarbonate $(400 \mathrm{mg}$ ) was added. The solvent was removed under vacuum, and the residue was diluted with water $(5 \mathrm{~mL})$ and extracted with ethyl acetate $(3 \times 10 \mathrm{~mL})$. The organic layer was dried with anhydrous sodium sulfate, 
concentrated in vacuo and the crude product was chromatographed on silica gel with n-hexane/ethyl acetate (85:15) as eluant, affording compound 6 in $46 \%$ yield. mp 264.6-266. $2^{\circ} \mathrm{C}$ (from chloroform/methanol). IR (KBr) $v_{\max }$ ' $\mathrm{cm}^{-1}: 3414\left(v_{\mathrm{OH}}\right) ; 1700\left(v_{\mathrm{C}=\mathrm{O}}\right) ; 1067$ and $1152\left(v_{\mathrm{C}-\mathrm{O}}\right) ; 977$, 898 and 865 (spiroketal system). ${ }^{1} \mathrm{H}$ NMR (DMSO- $d_{6}$ ): 0.68 $\left(3 \mathrm{H}, \mathrm{s}, \mathrm{CH}_{3}-18\right) ; 0.72\left(3 \mathrm{H}, \mathrm{d}, J 6.5 \mathrm{~Hz}, \mathrm{CH}_{3}-27\right) ; 0.85(3 \mathrm{H}, \mathrm{s}$, $\left.\mathrm{CH}_{3}-19\right) ; 0.89$ (3H, d, J $\left.6.6 \mathrm{~Hz}, \mathrm{CH}_{3}-21\right) ; 1.67$ (1H, d, J 15.4 $\mathrm{Hz}, \mathrm{H}-4 \alpha) ; 2.1(1 \mathrm{H}, \mathrm{dd}, J 3.2$ and $15.4 \mathrm{~Hz}, \mathrm{H}-4 \beta) ; 2.61(3 \mathrm{H}$, $\mathrm{m}, \mathrm{H}-7 \alpha, 7 \beta$ and $1 \alpha) ; 3.25\left(3 \mathrm{H}, \mathrm{s},-\mathrm{OCH}_{3}\right), 3.36(3 \mathrm{H}, \mathrm{m}, \mathrm{H}-$ $2 \alpha, \mathrm{H}-26_{\text {ax }}$ and $\left.\mathrm{H}-26_{\mathrm{eq}}\right) ; 4.04(1 \mathrm{H}, \mathrm{m}, \mathrm{H}-3 \beta) ; 4.33(1 \mathrm{H}, \mathrm{m}, \mathrm{H}-$ 16). ${ }^{13} \mathrm{C}$ NMR $\left(\mathrm{CDCl}_{3}\right)$ : see Table 1. Anal. Calcd. for $\mathrm{C}_{28} \mathrm{H}_{44} \mathrm{O}_{6} \mathrm{C} 70.55 \%, \mathrm{H} 9.31 \%$. Found C 70.59\%, H 9.26\%.

Table 1. ${ }^{13} \mathrm{C}$ NMR chemical shifts, $\delta$ (ppm), for compounds 3-6

\begin{tabular}{|c|c|c|c|c|}
\hline Carbon & 3 & 4 & 5 & 6 \\
\hline C-1 & 33.5 & 37.2 & 33.2 & 26.7 \\
\hline C-2 & 51.2 & 74.7 & 70.8 & 79.8 \\
\hline C-3 & 54.0 & 85.6 & 70.2 & 68.3 \\
\hline C-4 & 26.4 & 39.6 & 27.1 & 29.1 \\
\hline$C-5$ & 79.0 & 91.3 & $80.5^{*}$ & 80.4 \\
\hline C-6 & 209.4 & 208.3 & 212.1 & 211.8 \\
\hline C-7 & 42.0 & 44.9 & 41.4 & 41.4 \\
\hline C-8 & 37.4 & 39.7 & 36.3 & 36.2 \\
\hline C-9 & 45.7 & 48.4 & 45.1 & 45.0 \\
\hline C- -10 & 41.8 & 52.7 & 42.9 & 46.1 \\
\hline C-11 & 20.6 & 21.7 & 20.8 & 20.8 \\
\hline C-12 & 39.4 & 40.4 & 39.5 & 39.6 \\
\hline C-13 & 40.8 & 40.9 & 41.0 & 41.0 \\
\hline C-14 & 56.0 & 56.0 & 45.9 & $55.9^{\mathrm{a}}$ \\
\hline C-15 & 31.5 & 31.5 & 31.2 & 31.3 \\
\hline C-16 & 80.4 & 80.4 & $80.3^{a}$ & 80.0 \\
\hline C-17 & 62.0 & 61.9 & 61.2 & 61.9 \\
\hline C- -18 & 16.2 & 16.3 & 16.3 & 16.3 \\
\hline C-19 & 16.0 & 15.0 & 15.8 & 14.8 \\
\hline C-20 & 41.6 & 41.6 & 41.5 & 41.5 \\
\hline $\mathrm{C}-21$ & 14.4 & 14.5 & 14.2 & 14.3 \\
\hline $\mathrm{C}-22$ & 109.2 & 109.3 & 109.3 & 109.3 \\
\hline C-23 & 31.3 & 31.3 & 31.3 & 31.2 \\
\hline C-24 & 28.7 & 28.7 & 28.6 & 28.6 \\
\hline C-25 & 30.2 & 30.2 & 30.1 & 30.1 \\
\hline C-26 & 66.9 & 66.9 & 66.8 & 66.8 \\
\hline C-27 & 17.1 & 17.1 & 16.9 & 17.0 \\
\hline $\mathrm{C}-\mathrm{OCH}_{3}$ & & & & $56.6^{a}$ \\
\hline
\end{tabular}

assignments can be interchanged.

\section{Biological activity}

The biological activity of compounds $\mathbf{3 , 5}$ and $\mathbf{6}$ was tested by the radish (Raphanus sativus L.) hypocotyl elongation and cotyledon expansion bioassay. ${ }^{7}$ A mother solution of each of the compounds to be tested was prepared in ethanol, at $10^{-1} \mathrm{mg} \mathrm{mL}^{-1}$, and the samples diluted in water were applied in a concentration range of $10^{-4}$ to $10^{-7} \mathrm{mg} \mathrm{mL}^{-1}$.

\section{Acknowledgements}

We gratefully acknowledge the generous financial support of this work by FAPESP (grants 99/09687-0 and 99/07907-2) and University of Havana (Alma Mater Research Project).

\section{References}

1. Grove, M. D.; Spencer, F. G.; Rohwededer, W. K.; Mandava, N. B.; Worley, J. F.; Warthen Jr., J. D.; Steffens, G. L.; FlippenAnderson, J. L.; Cook Jr., J. C.; Nature 1979, 281, 216; Mandava, N. B.; Annu. Rev. Plant Physiol. Plant Mol. Biol. 1988, 39, 23; Kamuro, Y.; Takatsuto, S. In Brassinosteroids: Steroidal Plant Hormones; Sakurai, A.; Yokota, T.; Clouse, S. D., eds; Springer Verlag: Tokyo, 1999, ch.10; Khripach, V. A.; Zhabinskii, V.; de Groot, A. E.; Brassinosteroids, A New Class of Plant Hormones, Academic Press: San Diego, 1999, ch. 11.

2. Cutler, H. G. In Brassinosteroids: Chemistry, Bioactivity and Applications; Cutler, H. G.; Yokota, T.; Adam, G., eds; American Chemical Society: Washington, 1991, ch. 30; Núñez, M; Robaina, C. Brasinoesteroides. Nuevos Reguladores del Crecimiento Vegetal con Amplias Perspectivas para la Agricultura, Instituto Agronômico: Campinas, 2000, and the references cited therein; Khripach, V. A.; Zhabinskii, V. N.; Malevanaya, N. N.; Proceedings of the 24th Annual Meeting of the Plant Growth Regulation Society of America, Atlanta, USA, 1997, p.101.

3. Coll, M.F.; Jomarrón, R.I.M.; Robaina, R.C.M.; Alonso, B.E.M.; Cabrera, P.M.T.; PCT Int. Appl. WO 97/13780, 1995 (CA 126, 343720); Alonso, E.; PhD. Thesis, Universidad de La Habana, Cuba, 1990; Iglesias M.; Pérez R.; Leleibre V.; Pérez C.; Coll F.; J. Chem. Research (S) 1996, 504; Jomarrón, I.; PhD. Thesis; Universidad de La Habana, Cuba, 1995; Robaina, C.; PhD. Thesis; Universidad de La Habana, Cuba, 1994.

4. Kovganko, N. V.; Ananich, S.K.; Zhurn. Org. Khimii 1991, 27, 103 (CA 115: 72010u); Ramírez, J. A.; Centurion, O. M. T.; Gros E. G.; Galagovsky, L. R.; Steroids 2000, 65, 329.

5. Brosa, C.; Soca, L.; Terricabras, E.; Ferrer J. C.; Alsina, A.; Tetrahedron 1998, 54, 12337.

6. Hechavarría, M.; MSc. Thesis, Universidad de La Habana, Cuba, 1998.

7. Lethan, D. S. In Biochemistry and Physiology of Plant Growth Substances; Wightman, F.; Setterfield, G., eds.; Runge Press: Ottawa, 1968, ch. 2; Abreu, C.; Coll, D.; González, S.; Programas y Resúmenes del X Seminario Científico del INCA, San José de las Lajas, Cuba, 1996, p. 156.

Received: April 15, 2002

Published on the web: March 24, 2003

FAPESP helped in meeting the publication costs of this article. 